\title{
POTENSI PENGEMBANGAN PETERNAKAN AYAM RAS PETELUR DI KABUPATEN HALMAHERA BARAT
}

\author{
Fony Pelafu**, M. Najoan*, dan F. H. Elly* \\ **Program Pascasarjana, Universitas Sam Ratulangi Manado \\ *Fakultas Peternakan Universitas Sam Ratulangi Manado, 95115
}

\begin{abstract}
ABSTRAK
Penelitian ini bertujuan untuk menganalisis potensi dan kendala serta prioritas strategi. Responden dipilih secara sengaja yaitu peternak, pengambil kebijakan dan stakeholder terkait. Peternak umumnya berusia produktif dengan tingkat pendidikan kategori sedang, belum pernah mengikuti pelatihan dan tidak mempunyai pengalaman beternak. Sebagian besar peternak memiliki profesi sebagai petani. Status kepemilikan usaha merupakan milik kelompok dan pribadi serta sebagian besar menjadikan usaha peternakannya sebagai usaha sambilan untuk menambah pendapatan.Tatalaksana budidaya tidak dilakukan dengan benar sehingga populasi berfluktuatif dan produktivitasnya sangat rendah. Kekuatan utama adalah dukungan modal usaha dari pemerintah daerah dan pemasaran telur mudah. Kelemahan utama adalah minimnya informasi. Peluang utama adalah kebijakan pemerintah yang mendukung industri peternakan sangat kondusif dan ancaman terbesarnya adalah harga pakan yang cenderung fluktuatif. Alternatif strategi yang dihasilkan adalah meningkatkan pangsa pasar untuk meraih posisi market leader melalui kebijakan pemerintah daerah, meningkatkan kualitas SDM melalui pembinaan dan pendampingan untuk peningkatan produktifitas, menyediakan saran produksi peternakan khususnya pakan didaerah dengan memanfaatkan bahan baku lokal

\footnotetext{
* Korespondensi (Corresponding Author)
}

Email: femi_elly@yahoo.co.id
\end{abstract}

yang tersedia, dan menjalin kerjasama melalui pola kemitraan antara peternak dan pihak swasta. Berdasarkan analisis QSPM prioritas strategi yang dipilih adalah Menjalin kerjasama melalui pola kemitraan antara peternak dan pihak swasta/perusahaan Peternakan dengan nilai total TAS tertinggi yaitu sebesar 5,353.

Kata kunci : Strategi pengembangan ayam petelur, potensi Kabupaten Halmahera Barat..

\section{ABSTRACT}

THE DEVELOPMENT POTENTIAL OF LAYER POULTRY IN WEST HALMAHERA REGENCY.The objective of this study was to analyse the potential and constraints and strategic priority of laying hen development. Respondents were chosen purposively involving farmers, policy makers and related stakeholders. Breeders weregenerally in their productive age with medium education levels, the breeders who were not been trained and the breeders who had no breeding experience. Majority of breeders had the profession as farmers. The ownership status of the farm business belongs to both group and private, and most of them made their livestock business as a sideline to add their income. Management of cultivation wasnot done properly so that the population fluctuated, and productivity was very low. The main strength was business capital support from local government and egg marketing was 
relatively easy. The main weakness was the lack of information. The main opportunity was the government policy supporting the livestock industry in conducive situation and the biggest threat was the price of feed tending to fluctuate. The alternative strategy achieved were increasing the market share to achieve market leader position through local government policy, improving the quality of human resources through mentoring and assistance to increase productivity, providing livestock production facilities, especially feed in the area by utilizing available local raw materials, and establishing cooperation through partnership between farmers and the private company. Based on QSPM analysis, the priority of strategy chosen was to establish cooperation through partnership between breeder and private sector / Animal Husbandry Company with the highest total TAS value of 5,353.

Keywords: layerdevelopment strategy, West Halmahera regency potential.

\section{PENDAHULUAN}

Industri perunggasan memiliki nilai strategis khususnya dalam penyediaan protein hewani untuk memenuhi kebutuhan dalam negeri, disamping peranannya dalam memanfaatkan peluang kesempatan kerja. Salah satu industri perunggasan yang memiliki peran penting dalam penyediaan protein hewani masyarakat adalah peternakan ayam ras petelur yang menghasilkan produk telur konsumsi. Salah satu peternakan yang dikembangkan untuk menunjang protein hewani adalah peternakan ayam ras petelur (Ardhiana et al, 2014). Menurut
Widyantara dan Ardani (2017), peternakan ayam petelur memiliki peluang untuk dikembangkan. Purwaningsih (2014) menyatakan bahwa dalam dunia perunggasan, usaha peternakan ayam ras petelur mengalami perkembangan yang pesat dan umumnya bersifat komersial.

Industri perunggasan yang menjadi penyedia telur di Maluku Utara belum berkembang dengan baik. Kebutuhan telur di Maluku Utara khususnya Halmahera Barat sebagian besar masih didatangkan dari Manado dan Surabaya. Menurut Mappigau dan Esso (2011), budidaya ayam ras petelur memiliki potensi yang sangat menarik tetapi masih terdapat tantangan dalam pengembangannya. Tantangan tersebut dapat menjadi penghambat usaha sehingga potensi keuntungan dapat menjadi kerugian.

Tahun 2012, telur yang masuk ke Kabupaten Halmahera Barat sebanyak 2.851.200 butir dan terus mengalami peningkatan hingga tahun 2014 sebanyak 3.295.800 butir (Dinas Pertanian Halmahera Barat, 2015).Upaya pemerintah Halmahera Barat memenuhi kebutuhan telur di daerah sendiri dilakukan dengan memberikan bantuan ternak ayam petelur dan sarana produksinya kepada kelompok masyarakat tetapi usaha ini tidak berkembang dan bertahan secara produktif. Bantuan dimulai pada tahun 2005 dengan jumlah populasi sebanyak 4.500 ekor dan 
terus bertambah setiap tahunnya dengan populasi tertinggi pada tahun 2010sebanyak 19.481 ekor, dan produksi telurnya sebanyak $140.263 \mathrm{~kg}$. Tahun 2011 terjadi penurunan populasi yang cukup tajam dengan jumlah ayam tersisa 3.975 ekor, dan pada tahun 2012 terjadi penutupan usaha peternakan ayam ras petelur yang ada di Kabupaten Halmahera Barat (Dinas Pertanian Halmahera Barat, 2013).

Keadaan ini menjadi tantangan bagi pemerintah daerah dan swasta untuk menggiatkan kembali peternakan ayam ras petelur karenasangat prospektif untuk dikembangkan di Kabupaten Halmahera Barat, dilihat dari kecenderungan konsumsi telur yang terus meningkat setiap tahun. Penelitian ini bertujuan untuk menganalisis potensi dan kendala dan prioritas strategi pengembangan ayam ras petelur di Kabupaten Halmahera Barat.

\section{MATERI DAN METODE PENELITIAN}

Penelitian ini di Kabupaten Halmahera Barat Provinsi Maluku Utara dengan menggunakan metode survey. Data yang digunakan terdiri dari data primer dan data sekunder. Data primer merupakan data yang dikumpulkan melalui wawancara dan observasi langsung di lapangan dengan responden yang terkait dalam penelitian. Data sekunder diperoleh dari buku teks, artikel, laporan, jurnal serta data dari instansi pemerintah maupun swasta terkait yang relevan dengan penelitian. Metode penentuan responden dilakukan dengan cara sengaja (purposive sampling), dengan pertimbangan bahwa responden yang bersangkutan memiliki keahlian dan kompeten di bidangnya. Responden yang dipilih, yaitu : Kepala Bappeda Halmahera Barat, Kepala Dinas Pertanian Halmahera Barat, Kepala Bidang Peternakan Distan Halbar, Akademisi STPK Banau Halmahera Barat dan Pelaku usaha peternakan ayam ras petelur/Peternak. Metode analisis yang digunakan adalah analisis deskriptif kualitatif dan kuantitatif dengan menggunakan matriks Internal Factor Evaluation (IFE) dan matriks External Factor Evaluation (EFE), matriks Internal - External (I-E)dan Analisis SWOT untuk mengetahui posisi peternakan dan alternatif strategi yang diperlukan.Selanjutnya digunakan matriksQuantitative Strategic Planning (QSP)(David, 2012) untuk mengetahui prioritas strategi yang dapat diterapkan dalam pengembangan peternakan ayam ras petelur di Kabupaten Halmahera Barat.

\section{HASIL DAN PEMBAHASAN}


Hasil penelitian menunjukkan bahwa umur peternak berkisar antara $18-45$ tahun dengan presentase sebesar $85.7 \%$ dan diatas 45 tahun sebesar $14.3 \%$. Umur peternak dalam kisaran ini menurut Tatipikalawan (2012) adalah tenaga kerja usia produktif yaitu tenaga kerja yang mampu menghasilkan barang atau jasa, baik untuk memenuhi kebutuhan sendiri maupun untuk masyarakat. Indikasinya peternak masih mempunyai fisik yang kuat dan mampu mengelola peternakannya.

Usia produktif peternak juga ditunjang oleh tingkat pendidikan formal dari peternak. Tingkat pendidikan formal peternak termasuk dalam kategori sedang karena sebagian besar telah menyelesaikan Sekolah Menengah Tingkat Atas (SMTA), yaitu sebesar 71,4 persen. Hasil penelitian menunjukkan usia produktif dengan tingkat pendidikan kategori sedang tidak diikuti oleh pendidikan non formal yang baik. Secara keseluruhan, peternak belum pernah mengikuti pelatihan maupun seminar tentang ayam ras petelur.Peternak juga tidak memiliki pengalaman beternak ayam ras petelur karena merupakan peternak pemula. Peternak umumnya mempunyai pekerjaan utama selain beternak, sebanyak lima orang sebagai petani $(71.4$ $\%$ dan dua orang sebagai pedagang/pengusaha (28.6\%). Pekerjaan sebagai peternak sebagian besar $(85.7 \%)$ dikerjakan sebagai kerja sambilan untuk menambah pendapatan.

Hasil penelitian menunjukkan bahwa Kabupaten Halmahera Barat cukup potensial dan prospektif untuk pengembangan peternakan ayam ras petelur meskipun terdapat beberapa kendala yang perlu diatasi untuk keberhasilan usaha. Hal ini dapat dilihatdari faktor internal yaitu kekuatan dan kelemahan serta faktor eksternal yang terdiri dari peluang dan ancaman. Potensi yang dimilikiberupa kekuatan dan peluang antara lain : sumber daya lahan masih luas yang dapat dipergunakan untuk pembangunan kandang tanpa bersaing dengan lahan pertanian dan pemukiman penduduk, ketersediaan tenaga kerja dengan angkatan kerja yang cukup besar,mendapat dukungan modal usaha dari pemerintah daerah, kualitas telur dengan standar yang baik, pemasaran telur mudah, permintaan pasar telur yang cukup tinggi tetapi sangat bergantung pasokan dari luar daerah, kebijakan pemerintah yang mendukung indutri perunggasan sangat kondusif, kesadaran terhadap kebutuhan gizi meningkat, peluang kerjasama dengan investor dan selera konsumen yang tinggi terhadap telur lokal. Sedangkan kendala yang dihadapi berupa kelemahan dan ancaman, yaitu kualitas dan keterampilan peternak masih rendah, belum berfungsinya kelompok tani, 
terbatasnya infrastruktur dan teknologi peternakan, sistem pencatatan laporan produksi dan keuangan belum rapih, minimnya informasi, banyaknya telur yang masuk dari luar daerah, harga jual telur dari luar daerah lebih murah, lingkungan peternakan yang tidak kondusif, ketersediaan sarana produksi peternakan kurang terjamin dan harga pakan yang cenderung fluktuatif.

\section{Analisis matriks Internal Factor}

Evaluation (MatriksIFE) menunjukkan bahwa skor tertinggi pada faktor kekuatan adalah dukungan modal usaha dari pemerintah daerah dan pemasaran telur mudahdengan skor 0,421 . Skor terendah adalah potensi sumber daya lahan yang luas dengan skor 0,075 . Sedangkan pada faktor kelemahan, kelemahan terbesar adalah minimnya informasi dengan skor 0,240 dan skor terendah pada kualitas dan keterampilan peternak masih rendah dengan skor 0,109 . Total skor matriks IFE untuk pengembangan peternakan ayam ras petelur di Kabupaten Halmahera Barat berada pada skor 2,512. Hal ini menunjukan bahwa situasi internal usaha peternakan ayam ras petelur berada pada tingkat rata-rata (Tabel 1).

Analisis matriks Eksternal Factor Evaluation (MatriksEFE) menunjukan bahwa skor tertinggi pada peluang adalah kebijakan pemerintah yang mendukung industri peternakan sangat kondusif dengan skor 0,359 dan peluang terendah adalah kesadaran masyarakat terhadap kebutuhan gizi meningkat dengan skor 0,266. Sedangkan pada faktor ancaman, ancaman terbesar adalah harga pakan yang cenderung fluktuatif dengan skor 0,146 dan ancaman terendah adalah banyaknya telur yang masuk dari luar daerah. Total skor matriks EFE pada usaha peternakan ayam ras petelur adalah 2,218.

Tabel 1. Analisis Matriks IFE

\begin{tabular}{|c|c|c|c|}
\hline Faktor Internal & Bobot & Rating & Skor Bobot \\
\hline \multicolumn{4}{|l|}{ Kekuatan } \\
\hline 1. Potensi sumber daya lahan yang luas & 0,075 & 4 & 0,299 \\
\hline 2. Tersedianya tenaga kerja yang cukup & 0,083 & 4 & 0,312 \\
\hline 3. Dukungan modal usaha dari pemerintah daerah & 0,105 & 4 & 0,421 \\
\hline 4. Kualitas telur dengan strandar yang baik & 0,093 & 3 & 0,301 \\
\hline 5. Pemasarannya mudah, langsung diambil pedagang & 0,105 & 4 & 0,421 \\
\hline \multicolumn{4}{|l|}{ Kelemahan } \\
\hline 1. Kualitas dan keterampilan peternak masih rendah & 0,109 & 1 & 0,109 \\
\hline 2. Belum berfungsinya kelompok tani & 0,084 & 2 & 0,127 \\
\hline 3. Terbatasnya infrastruktur dan teknologi peternakan & 0,089 & 2 & 0,133 \\
\hline 4. Sistem pencatatan laporan produksi dan keuangan belum rapih & 0,119 & 1 & 0,149 \\
\hline 5. Minimnya informasi & 0,137 & 2 & 0,240 \\
\hline Total & $\mathbf{1 , 0 0 0}$ & & 2,512 \\
\hline
\end{tabular}

Sumber: Analisis Data Primer, (2016) 
Tabel 2. Analisis Matriks EFE

\begin{tabular}{lccc}
\hline \multicolumn{1}{c}{ Faktor Eksternal } & Bobot & Rating & Skor Bobot \\
\hline $\begin{array}{l}\text { Peluang } \\
\text { 1. Permintaan pasar terhadap telur yang cukup tinggi }\end{array}$ & 0,083 & 4 & 0,332 \\
2. Kebijakan pemerintah yang mendukungindustri peternakan & 0,096 & 4 & 0,359 \\
$\quad \begin{array}{l}\text { sangat kondusif } \\
\text { 3. Kesadaran masyarakat terhadap kebutuhan gizi meningkat }\end{array}$ & 0,082 & 3 & 0,266 \\
4. Peluang kerjasama dengan investor & 0,100 & 4 & 0,350 \\
5. Selera konsumen yang tinggi terhadap telur local & 0,089 & 4 & 0,333 \\
Ancaman & & & \\
1. Banyaknya telur yang masuk dari luar daerah & 0,076 & 1 & 0,076 \\
2. Harga jual telur dari luar daerah lebih murah & 0,079 & 1 & 0,079 \\
3. Lingkungan peternakan yang tidak kondusif & 0,108 & 1 & 0,135 \\
4. Ketersediaan sarana produksi peternakan (sapronak) & 0,139 & 1 & 0,139 \\
$\quad$ kurang terjamin & & & 0,148 \\
5. Harga pakan yang cenderung fluktuatif & 0,148 & 1 & $\mathbf{2 , 2 1 8}$ \\
\hline
\end{tabular}

Sumber : Analisis Data Primer (2016)

Hal ini menunjukan bahwa kondisi ekternal usaha peternakan ayam ras petelur berada dibawah rata-rata (Tabel 2).

Matriks Internal Eksternal (IE)menempatkan posisi suatu usaha kedalam tampilan sembilan sel dan menunjukan strategi apa yang harus diambil berdasarkan posisi tersebut. Menurut Rangkuti (2013) tujuan penggunaan matriks IE adalah untuk memperoleh strategi bisnis yang lebih detail dari suatu usaha. Berdasarkan analisis matriks IFE dan EFE, diperoleh total skor bobot matriks IFE dan matriks EFE masing-masing adalah 2,512 dan 2,218, sehingga peternakan ayam ras petelur di Kabupaten Halmahera Barat berada pada sel V yaitu Hold and Maintain (Gambar1).

\section{Total Skor Bobot IFE}

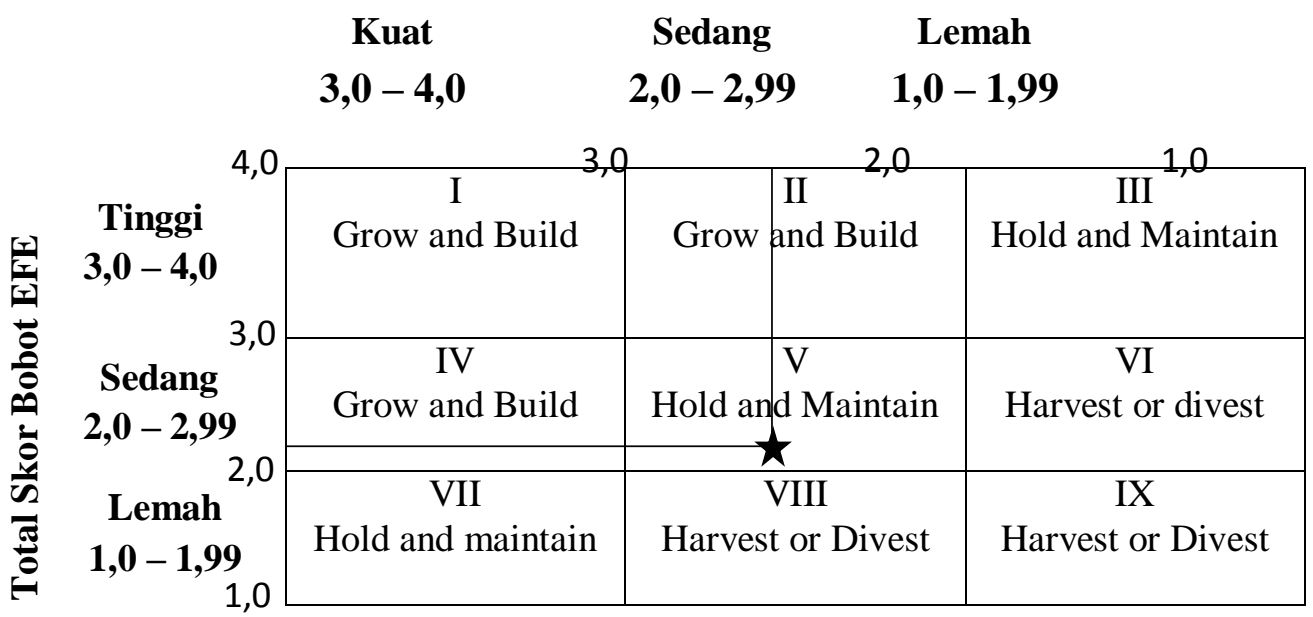

Gambar 1. Analisis Matriks IE 
Menurut Rangkuti (2013) strategi yang cocok untuk daerah ini adalah konsolidasi. Perusahaan yang berada pada sel ini dapat memperluas pasar, fasilitas produksi, dan teknologi melalui pengembangan internal dan eksternal melalui akuisisi atau joint ventures dengan perusahaan lain yang lebih kuat dalam usaha yang sama. Pada posisi ini, seharusnya usaha peternakan ayam ras petelur di Kabupaten Halmahera Barat dapat bermitra dengan usaha atau perusahaan peternakan ayam yang lebih kuat sehingga usaha dapat terjaga dan dipertahankan mengingat kekuatan yang dimiliki dan peluang yang tersedia sangat mendukung usaha pengembangan peternakan ayam ras petelur.

Analisis faktor internal dan eksternal adalah suatu analisis yang dapat memberikan gambaran bagaimana strategi dalam pengembangan bisnis.Hal ini termasuk bagaimana strategi pemasaran telur (Ommani, 2011; Abubakar dan Bello, 2013; Osita et al. 2014). Lestari dan Triani (2013) menyatakan bahwa suatu perusahaan memerlukan strategi yang efektif untuk dapat mencapai recovery atau keberhasilan turnaround.

Proses pencocokan antara elemen kekuatan, kelemahan, peluang dan ancaman dilakukan setelah analisis matriks
IFE dan EFE, dengan menggunakan matriks SWOT yang dinyatakan dalam matriks QSP (Tabel 3). Matriks Perencanaan Strategis Kuantitatif (Quantitative Strategic Planning MatrixQSPM) dirancang untuk menentukan daya tarik relatif dari berbagai tindakan alternatif. QSPM menggunakan analisis input pada tahap 1 (matriks IFE dan EFE) dan hasil pencocokan dari analisis tahap 2 (matriks SWOT). Teknik ini secara objektif menunjukkan strategi mana yang terbaik dari beberapa alternatif strategi yang dihasilkan. Analisis SWOT menurut Kurniawan et al (2013) adalah metode perencanaan strategi yang digunakan untuk mengevaluasi kekuatan, kelemahan, peluang dan ancaman dalam suatu spekulasi bisnis.

Berdasarkan analisis SWOT, untuk penentuan kebijakan dilakukan dengan mengembangkan empat (4) strategi, yaitu : (1) Strategi SO (Strenghts Opportunities), menghasilkan strategi "Peningkatan pangsa pasar untuk meraih posisi market leader melalui kebijakan dari pemerintah daerah".Strategi ini dijalankan dengan memperbesar jumlah populasi ternak ayam ras petelur sehingga produksi telurmeningkat,tujuannya agar dapat menguasai pasar lokal yang berdampak terhadap adanya peluang pasar. 
Tabel 3. Analisis Matriks QSP

\begin{tabular}{|c|c|c|c|c|c|c|c|c|c|}
\hline \multirow{3}{*}{ Faktor-Faktor Utama } & \multirow{3}{*}{ Bobot } & \multicolumn{8}{|c|}{ Alternatif Strategi } \\
\hline & & \multicolumn{2}{|c|}{$\begin{array}{c}\text { Strategi } \\
1\end{array}$} & \multicolumn{2}{|c|}{$\begin{array}{l}\text { Strategi } \\
2\end{array}$} & \multicolumn{2}{|c|}{$\begin{array}{c}\text { Strategi } \\
3\end{array}$} & \multicolumn{2}{|c|}{$\begin{array}{c}\text { Strategi } \\
4\end{array}$} \\
\hline & & $\mathbf{A S}$ & TAS & $\overline{\mathrm{AS}}$ & TAS & $\overline{\mathrm{AS}}$ & TAS & $\mathbf{A S}$ & TAS \\
\hline \multicolumn{10}{|l|}{ Kekuatan } \\
\hline $\begin{array}{l}\text { 1. Potensi sumber daya lahan yang } \\
\text { luas }\end{array}$ & 0,075 & 3 & 0,187 & 1 & 0,075 & 4 & 0,299 & 3 & 0,187 \\
\hline $\begin{array}{l}\text { 2. Tersedianya tenaga kerja yang } \\
\text { cukup }\end{array}$ & 0,083 & 3 & 0,208 & 4 & 0,333 & 2 & 0,166 & 3 & 0,249 \\
\hline $\begin{array}{l}\text { 3. Dukungan modal usaha dari } \\
\text { pemerintah daerah }\end{array}$ & 0,105 & 4 & 0,421 & 2 & 0,158 & 2 & 0,211 & 3 & 0,316 \\
\hline 4. Kualitas telurnya baik & 0,093 & 4 & 0,371 & 2 & 0,185 & 2 & 0,185 & 2 & 0,185 \\
\hline $\begin{array}{l}\text { 5. Pemasarannya mudah, langsung } \\
\text { diambil pedagang }\end{array}$ & 0,105 & 4 & 0,421 & 2 & 0,210 & 2 & 0,158 & 3 & 0,263 \\
\hline \multicolumn{10}{|l|}{ Kelemahan } \\
\hline $\begin{array}{l}\text { 1. Kualitas dan keterampilan } \\
\text { peternak masih rendah }\end{array}$ & 0,109 & 2 & 0,219 & 4 & 0,438 & 1 & 0,109 & 3 & 0,328 \\
\hline $\begin{array}{l}\text { 6. Belum berfungsinya kelompok } \\
\text { tani }\end{array}$ & 0,084 & 1 & 0,084 & 4 & 0,338 & 2 & 0,169 & 3 & 0,253 \\
\hline $\begin{array}{l}\text { 7. Terbatasnya infrastruktur dan } \\
\text { teknologi peternakan }\end{array}$ & 0,089 & 1 & 0,089 & 3 & 0,266 & 2 & 0,177 & 4 & 0,355 \\
\hline $\begin{array}{l}\text { 8. Sistem pencatatan laporan } \\
\text { produksi dan keuangan belum } \\
\text { rapih }\end{array}$ & 0,119 & 2 & 0,179 & 3 & 0,357 & 1 & 0,060 & 4 & 0,476 \\
\hline 9. Minimnya informasi & 0,137 & 1 & 0,137 & 4 & 0,480 & 2 & 0,274 & 4 & 0,480 \\
\hline Total & 1,000 & & & & & & & & \\
\hline \multicolumn{10}{|l|}{ Peluang } \\
\hline $\begin{array}{l}\text { 1. Permintaan pasar terhadap telur } \\
\text { yang cukup tinggi }\end{array}$ & 0,083 & 4 & 0,332 & 3 & 0,249 & 1 & 0,083 & 2 & 0,166 \\
\hline $\begin{array}{l}\text { 2. Kebijakan pemerintah yang } \\
\text { mendukung 216ndustry } \\
\text { peternakan sangat kondusif }\end{array}$ & 0,096 & 4 & 0,383 & 2 & 0,191 & 3 & 0,287 & 1 & 0,096 \\
\hline $\begin{array}{l}\text { 3. Kesadaran masyarakat terhadap } \\
\text { kebutuhan gizi meningkat }\end{array}$ & 0,082 & 4 & 0,328 & 3 & 0,246 & 1 & 0,082 & 2 & 0,164 \\
\hline $\begin{array}{l}\text { 4. Peluang kerjasama dengan } \\
\text { investor }\end{array}$ & 0,100 & 4 & 0,350 & 4 & 0,350 & 2 & 0,150 & 2 & 0,150 \\
\hline $\begin{array}{l}\text { 5. Selera konsumen yang tinggi } \\
\text { terhadap telur local } \\
\text { Ancaman }\end{array}$ & 0,089 & 4 & 0,356 & 3 & 0,267 & 2 & 0,133 & 2 & 0,133 \\
\hline $\begin{array}{l}\text { 1. Banyaknya telur yang masuk dari } \\
\text { luar daerah }\end{array}$ & 0,076 & 4 & 0,303 & 3 & 0,190 & 1 & 0,076 & 2 & 0,152 \\
\hline $\begin{array}{l}\text { 2. Harga jual telur dari luar daerah } \\
\text { lebih murah }\end{array}$ & 0,079 & 4 & 0,276 & 2 & 0,158 & 4 & 0,276 & 2 & 0,158 \\
\hline $\begin{array}{l}\text { 3. Lingkungan peternakan yang } \\
\text { tidak kondusif }\end{array}$ & 0,108 & 1 & 0,108 & 2 & 0,216 & 0 & 0,000 & 4 & 0,378 \\
\hline $\begin{array}{l}\text { 4. Ketersediaan sarana produksi } \\
\text { peternakan (sapronak) yang } \\
\text { kurang terjamin }\end{array}$ & 0,139 & 1 & 0,139 & 2 & 0,279 & 4 & 0,558 & 3 & 0,418 \\
\hline $\begin{array}{l}\text { 5. Harga pakan yang cenderung } \\
\text { fluktuatif }\end{array}$ & 0,148 & 2 & 0,296 & 1 & 0,148 & 4 & 0,592 & 3 & 0,444 \\
\hline Total & 1,000 & & & & & & & & \\
\hline Prioritas Strategi & & & 5,187 & & 5,134 & & 4,046 & & 5,353 \\
\hline
\end{tabular}


Menurut Zaini (2011) bahwa
masuknya luar daerah $\begin{aligned} & \text { dapat } \\ & \text { menyebabkan persaingan harga;(2) }\end{aligned}$

Strategi WO (Weaknesses -

Opportunities), menghasilkan strategi

"Peningkatan kualitas sumber daya manusia (SDM) melalui pembinaan dan pendampingan untuk peningkatan produktivitas". Strategi ini dijalankan dengan memberikan pelatihan-pelatihan dan pembimbingan kepada peternak untuk meningkatkan keterampilan peternak dalam menjalankan usaha sehingga produktivitasnya meningkat. Peningkatan produktivitas membuat peternak dapat memenuhi permintaan pasar telur yang cukup tinggi dan meraih peluang kerjasama dengan investor; (3) Strategi ST (Strenghts - Threats), yang menghasilkan strategi "Penyediaan sarana produksi peternakan khususnya pakan di daerah dengan memanfaatkan bahan baku lokal yang tersedia". Strategi ini dijalankan dengan memanfaatkan sumber daya alam/potensi lokal yang ada untuk pembuatan pakan ternak guna mengurangi ketergantungan pakan dari luar daerah. Hal ini juga dapat menekan biaya produksi sehingga harga telur bisa bersaing dengan telur dari luar daerah. (4) Strategi WT (Weaknesses - Threats), merupakan taktik defensif yang diarahkan untuk mengurangi kelemahan internal serta menghindari ancaman eksternal, menghasilkan strategi "Terjalinnya kerjasama melalui pola kemitraan antara peternak dan pihak swasta/perusahaan peternakan". Strategi ini dijalankan melalui kerjasama antara peternak dengan perusahaan peternakan dalam penyediaan bibit, pakan dan sarana produksi lainnya. Kemitraan akan menguntungkan karena peternak dapat turut mengambil bagian manfaat dari pasar, modal, teknologi dan manajemen yang dikuasai perusahaan besar. Strategi dalam pengembangan ayam ras petelur menurut Kurniawan et al (2011) adalah strategi pertumbuhan agresif.

\section{KESIMPULAN DAN SARAN}

Berdasarkan hasil penelitian dapat disimpulkan bahwa potensi utama pengembangan peternakan ayamras peteluradalah dukungan modal usaha dari pemerintah daerah, pemasaran telurnya mudah dan kebijakan pemerintah yang mendukung industri perunggasan sangat kondusif. Sedangkan kendala utama adalah minimnya informasi dan harga pakan yang cenderung fluktuatif. Prioritas strategi yang dipilih berdasarkan analisis QSPM adalah menjalin kerjasama melalui pola kemitraan antara peternak dan pihak swasta/perusahaan peternakan dengan nilai total TAS tertinggi yaitu sebesar 5,353. 
Berdasarkan hasil penelitian disarankan perlu intervensi pemerintah melalui penjajakan kerjasama dengan perusahaan peternakan ayam besar untuk bermitra, memaksimalkan kegiatan penyuluhan dan pendampingan, serta memberikan solusi yang tepat berkaitan dengan pendanaan.

\section{DAFTAR PUSTAKA}

Abubakar, N and G.B. Bello. 2013. Strength, Weaknesses, Opportunities and Threats (SWOT) Analysis on Globacom Ltd. International Journal of Technology and Business Management 16 (1) : 83-91.

Ardhiana, M.Y., B.A. Nugroho., dan B. Hartanto. 2014. Efisiensi Pemasaran Telur Ayam Ras di Kecamatan Ringinrejo Kabupaten Kediri. Jurnal Fakultas Peternakan 2 (1): 1-13.

David, F.R. 2012. Manajemen Strategis,Edisi 12. Terjemahan oleh Dono Sunardi. Penerbit Salemba Empat. Jakarta

Dinas Pertanian Kabupaten Halmahera Barat. 2013. Data Populasi Ternak di Kabupaten Halmahera Barat Tahun 2013. Dinas Pertanian Kabupaten Halmahera Barat. Jailolo.

Dinas Pertanian Kabupaten Halmahera Barat. 2015. Data Populasi Ternak di Kabupaten Halmahera Barat Tahun 2015. Dinas Pertanian Kabupaten Halmahera Barat. Jailolo.
Kurniawan, H., B. Guntoro dan Wihandoyo. 2011. Strategi Pengembangan Ayam Ras Petelur di Kota Samarinda dan Kalimantan Timur. Buletin Peternakan, 35 (1) : 57-63.

Kurniawan, M.F.T., D.P. Darmawan dan N.W.S. Astiti. 2013. Strategi Pengembangan Agribisnis Ayam Petelur di Kabupaten Tabana. Jurnal Manajemen Agribisnis, 1 (2) : 5366.

Lestari, R.D dan N.N.A. Triani. 2013. Determinan Keberhasilan Turnaround pada Perusahaan yang Mengalami Financial Distress. Jurnal Ilmu Manajemen 1 (4) : 1142-1154.

Mappigau, P dan A.S.R. Esso. 2011. Analisis Strategi Pemasaran Telur pada Peternakan Ayam Ras Skala Besar di Kabupaten Sidrap. Jurnal Agribisnis X (3) :14-31.

Ommani, A.R. 2011. Strength, Weaknesses, Opportunities and Threats (SWOT) Analysis for Farming System Businesses Management : Case of Wheat Farmers of Shadervan District, Shoushtar Township, Iran. African Journal of Business Management 5 (22) : 9448-9454.

Osita, I.C., I. Onyebuchi and N. Justina. 2014. Organization's Stability and Productivity : the Role of SWOT Analysis on Acronym for Strength, Weaknesses, Opportunities and Threats. International Journal of Innovative and Applied Research 2 (9):25-52.

Purwaningsih, D.L. 2014. Peternakan Ayam Ras Petelur di Kota Singkawang. Jurnal online 
Mahasiswa Arsitektur Universitas Tanjungpura 2 (2) : 74-88.

Rangkuti. 2013. Analisis SWOT. PT Gramedia Pustaka Utama, Jakarta.

Tatipikilawan, J. M. 2012. Analisis Produktivitas Tenaga Kerja Keluarga pada Usaha Peternakan Kerbau di Pulau Moa Kabupaten Maluku Barat daya. Jurnal Agroforestri 7 (1) : 9-10, 12.
Widyantara, I.N.P dan I.G.A.K.S. Ardani. 2017. Analisis Strategi Pemasaran Telur Ayam (Studi Kasus di Desa Pesedahan dan Bugbug, Kabupaten Karangaem). E-Jurnal Manajemen Unud 6 (7): 3766-3793.

Zaini, A. 2011. Analisis Prospek Pemasaran Ayam Petelur di Kalimantan Timur. Jurnal EPP 8 (1): $1-8$. 